\title{
QUODVULTDEUS' SERMONS ON THE CREED: A REASSESSMENT OF HIS POLEMICS AGAINST THE JEWS, PAGANS, AND ARIANS**
}

The turn of the $4^{\text {th }}$ and $5^{\text {th }}$ century is very often portrayed as an era of significant advancement for orthodox Christianity (where orthodoxy refers to the right doctrine rather than to our times' Orthodox Churches). The legislation of Theodosius set the Christianity confessed by Peter as the privileged belief of the Roman people and its Emperors ${ }^{1}$. The life of Jews started to be regulated in relation to Christians. The efforts of the pagan nobility in Rome under the leadership of Symmachus and Praetextatus in the 380s were brought to an end by Theodosius' victory at the river Frigidus in $396^{2}$. Indeed, Arianism seemed to have been defeated at the councils of Constantinople and Aquileia in 381. Still, it is quite clear that Arianism and other heretical doctrines survived through the $5^{\text {th }}$ century, as the many polemical writings of Augustine bear witness to ${ }^{3}$. A group of pseudo-Augustinian sermons attributed to the Bishop of Carthage, Quodvultdeus, and composed towards the end of the 430s attests to the continuing polemics against Jews, pagans, and especially Arians ${ }^{4}$. Quodvultdeus is an excellent witness to the first generation of post-Augustinian theologians and pastors. He asked Augustine to write De haeresibus, which is a handbook

${ }^{*}$ Rev. dr David Vopřada - Centre for Patristic, Medieval, and Renaissance Texts, Sts. Cyril and Methodius Faculty of Theology, Palacký University in Olomouc; e-mail: voprada@ktf.cuni.cz.

${ }^{* *}$ This study is a result of research funded by the Czech Science Foundation under the project GA ČR P401/12/G168, "History and Interpretation of the Bible".

${ }^{1}$ Cf. CTh XVI 1, 2, issued on February 27, 380, and addressed to the people of Constantinople. The impact of this legislation is examined by J. Gaudemet, L'Edit de Thessalonique: police locale ou déclaration de principe?, in: Aspects of the Fourth Century A.D. Proceedings of the symposium Power \& possession: State, society, and church in the fourth century A.D. held on the occasion of the fifth anniversary of the interdisciplinary debating society AGAPE. Leiden, 3-5 June 1993, ed. H.W. Pleket - A.M.F.W. Verhoogt, Leiden 1997, 43-51; M.V. Escribano Paño, El Edicto de Tesalónica (CTh 16, 1, 2. 380) y Teodosio: norma antiarriana y declaración programática, "Cassiodorus" 5 (1999) 35.

${ }^{2}$ Cf. A. Cameron, The Last Pagans of Rome, Oxford 2011, 93-131.

${ }^{3}$ Cf. M.R. Mara, Arriani, AL I 450-459 and bibliography listed there.

${ }^{4}$ The Quodvultdean research has been recently studied by A.V. Nazzaro, La produzione omiletica del vescovo di Cartagine Quoduultdeus, in: Le forme e i luoghi della predicazione. Atti del Seminario internazionale di studi (Macerata 21-23 novembre 2006), ed. G. Frenguelli - C. Micaelli, Macerata 2009, 26-67. 
addressed to the clergy of Carthage acquainting them with the most prominent heresies and doctrines ${ }^{5}$. With the eventual fall of Africa into the hands of the Vandals led by Geiseric in the 430s, the situation for Roman citizens in Africa (mostly Catholics) changed radically. Quodvultdeus, Bishop of Carthage from around $432 / 433^{6}$, had to contend with the fact that Catholic Christianity was no longer a privileged faith protected by the Emperors, but one that had become a religious entity persecuted by the new Arian rulers ${ }^{7}$. The Catholic basilicas were taken together with the property of the Church. The clergy were persecuted, and even Quodvultdeus had to face punishment: half a century later, Victor of Vita narrates how Geiseric forced him and his clergy naked onto a sinking ship. Surprisingly, the ship made it to Naples in Campania where Quodvultdeus would live as an exile for another fifteen years of his life.

As already mentioned, Quodvultdeus' sermons are considered highly polemical, targeting all non-Catholic religious groups present in his days in Africa, in particular the Pagans, Jews, and Arians ${ }^{8}$. In fact, the bishop's sermons contain violent and uncompromising attacks on these non-Catholic groups. In his De promissionibus et praedicationibus Dei as well as in his sermons, Quodvultdeus goes so far as to identify heretics with the Antichrist ${ }^{9}$. This portrayal of Quodvultdeus as an anti-heretical polemist is believed to correspond with his previous interest in heresies as a deacon, exemplified by his request for Augustine to write De haeresibus.

1. Quodvultdeus' harsh anti-heretical language. In fact, the language Quodvultdeus uses when speaking about heretics, especially Arians,

${ }^{5}$ It was G. Morin, Pour une future édition des opuscules de s. Quodvultdeus évêque de Carthage au Ve siècle, RBen 31 (1914-1919) 157 and 161, who suggested that deacon Quodvultdeus, who wrote two letters to Augustine (Epistulae 221 and 223 in Augustine's epistolary), was the same man as Quodvultdeus, the Bishop of Carthage. The arguments in favour of this probability in view of later research are discussed by D. Van Slyke, Quodvultdeus of Carthage. The Apocalyptic Theology of a Roman African in Exile, Strathfield 2003, 51-53.

${ }^{6}$ Cf. R. González Salinero, Poder y conflicto religioso en el norte de África: Quodvultdeus de Cartago y los vándalos, Madrid 2002, 36.

${ }^{7}$ A. Rodolfi (A Difficult Co-Existence in Vandal Africa: King Geiseric and the Catholics, StPatr 39:2006, 117-123) discusses not only the religious, but also the political motivations of Geiseric's move against the Roman citizens of Nicene faith. For the history of Arianism in Africa, cf. R. Whelan, Arianism in Africa, in: Arianism: Roman Heresy and Barbarian Creed, ed. G.M. Berndt - R. Steinacher, Farnham 2014, 239-255. Research on the history of Arianism as such was recently presented by J.T. Leinhard, From Gwatkin Onwards: A Guide through a Century and a Quarter of Studies on Arianism, AugSt 44 (2013) 265-285.

${ }^{8}$ Cf. Morin, Pour une future édition, p. 156, and other researchers to have followed him.

${ }^{9}$ Cf. Quodvultdeus, De promissionibus et praedicationibus Dei IV 10, 18, ed. R. Braun, CCL 60, Turnhout 1976, 203, and the invectives launched against heretics in the next chapter. This association of heretics with the Antichrist was already traditional in African theology: cf. Cyprianus, Epistula 69, 1, 2, ed. W. Hartel, CSEL 3/2, Vindobonae 1871, 470-471. 
is unyielding. He does not baulk from calling them "insane"10, "unlearned", "stupid"11, "impious"12, or "blasphemous"13. He even addresses them using an apostrophe: "O evil wolf, o wicked serpent! O wretched servant!" ${ }^{14}$. He speaks about their ever-growing "excesses"15 and accuses them of deceiving true Christians with flattering words ${ }^{16}$. He compares them to "dogs raging" against the Lord, who, in their lack of awareness of divine things, insult Christ's humility by lifting up their necks and vibrating their tongues ${ }^{17}$. He charges them for their abuse of the Mother Church ${ }^{18}$, labels them "persecutors" 19 , and speaks of their "malevolent" spirit ${ }^{20}$. He describes them as "thieves", "robbers", "the most wretched wolf-abductors", and posing a danger for the sheep of the supreme shepherd" ${ }^{21}$. In his view, congregations that "lurk in the corner of any heresy" are "concubines"; women divorced from Christ ${ }^{22}$. He even questions the reasoning of the Arians by describing their ways through the words of the psalm: "The impious walk in circles"23. Their teachings and attitudes are not only "grave errors separating from the Catholic doctrine" 24 , but also "perverse"25, the "crafty devices of wolves"26, "mad obstinacy"27.

Quodvultdeus' rhetoric follows the ancient Christian catechesis, already present in the Apostolic Fathers, in two ways ${ }^{28}$. For him, the contrast between true faith and heresy is the same as that between truth and falsity, possession of faith and confusion, eternal sweetness and the worst bitterness, secure ex-

${ }^{10}$ Cf. Quodvultdeus, Contra Iudaeos, Paganos et Arrianos 5, 6, ed. R. Braun, CCL 60, 234: "insane haeretice".

${ }^{11}$ Cf. idem, De accedentibus ad gratiam 1, 13, 1, ed. R. Braun, CCL 60, 451.

${ }^{12}$ Cf. idem, De symbolo 1, 9, 9, ed. R. Braun, CCL 60, 327: "impii sunt".

${ }^{13}$ Cf. idem, Contra Iudaeos, Paganos et Arrianos 19, 2, CCL 60, 254: “Arriani blasphemantes".

${ }^{14}$ Cf. idem, De symbolo 1, 13, 6, CCL 60, 334: "O lupe male! o serpens inique! o serve nequissime!"

${ }^{15}$ Cf. idem, Contra Iudaeos, Paganos et Arrianos 19, 3, CCL 60, 254: "sentisne quo progressa fuerit immanitas tua?"

${ }^{16}$ Cf. ibidem 19, 7, CCL 60, 255.

${ }^{17} \mathrm{Cf}$. idem, De accedentibus ad gratiam 1, 8, 13, CCL 60, 447.

${ }^{18} \mathrm{Cf}$. idem, De symbolo 1, 13, 4, CCL 60, 334.

${ }^{19}$ Cf. ibidem 3, 4, 19, CCL 60, 355: "persequentes".

${ }^{20}$ Cf. ibidem 1, 4, 32, CCL 60, 316: "malivolam animam".

${ }^{21}$ Cf. ibidem 3, 9, 11, CCL 60, 361.

${ }^{22}$ Cf. ibidem 3, 13, 4, CCL 60, 363.

${ }^{23}$ Cf. ibidem 1, 9, 9, CCL 60, 327: "In circuiti impii ambulant" (Ps 11:9).

${ }^{24}$ Cf. ibidem 3, 9, 9, CCL 60, 361: "malus error a catholica doctrina separans".

${ }^{25} \mathrm{Cf}$. ibidem 1, 4, 18, CCL 60, 314; 1, 4, 32, CCL 60, 316: "perversam vestram doctrinam; perversis quae sunt in vobis"; 2, 2, 5, CCL 60, 336; idem, De accedentibus ad gratiam 1, 14, 5, CCL 60, 453.

${ }^{26}$ Cf. idem, De symbolo 3, 9, 10, CCL 60, 361: "insidias luporum".

${ }^{27}$ Cf. idem, Contra Iudaeos, Paganos et Arrianos 5, 5, CCL 60, 234: "insana contumacia".

${ }^{28}$ Cf. ibidem 21, 1 ff, CCL 60, 256; Didache 1-6, ed. A. Lindemann - H. Paulsen, in: Die Apostolischen Väter, Tübingen 1992, 4-12; Epistula Pseudo-Barnabae 18, 1 - 21, 1, ed. A. Lindemann - H. Paulsen, in: Die Apostolischen Väter, p. 68-72. 
ultation and dangerous self-elation, life and death, joy and sorrow ${ }^{29}$. He even compares their practice of persuading Catholics to join their ranks with Judas selling Christ to the Jews, addressing the Arians: "Heretic, you do far worse than the Jew did!" 30 . His figurative language probably reaches its climax when he implicitly compares the Vandal rulers to King Herod, who slayed innocent children $^{31}$, i.e. faithful Catholic Christians. Indeed, he conflates the devil himself, the adversary of Christ, with these heretical rulers ${ }^{32}$.

However, this stiff language alone is not necessarily enough to depict Quodvultdeus as an anti-heretical polemicist. For if we frame these invectives in the liturgical context of the sermons, preached in part in the course of the instruction of candidates for baptism, if we consider the religious and historical contexts, and if we compare Quodvultdeus' sermons to analogical patristic writings, a different image of Quodvultdeus emerges. The topic I would like to present briefly in this paper focuses on the sermons addressed to candidates for baptism on the occasion of the traditio symboli. These include three sermons De symbolo ${ }^{33}$, a sermon entitled Contra Iudaeos, paganos et Arianos, and two sermons De accedentibus ad gratiam $^{34}$. This will hopefully help to reassess the polemical aspect of Quodvultdeus' theology and offer a basis for further study of Quodvultdeus' thought and pastoral efforts.

2. Liturgical context. Crucial to the understanding of Quodvultdeus' intentions is the liturgical context of the above sermons ${ }^{35}$. They were given before baptism, on the occasion of handing over the baptismal Creed or at least very soon after the pre-baptismal rite ${ }^{36}$. The bishop's task was to instruct the com-

${ }^{29}$ Cf. Quodvultdeus, Contra Iudaeos, Paganos et Arrianos 21, 1-3, CCL 60, 256.

${ }^{30}$ Idem, De symbolo 1, 13, 9, CCL 60, 334: "Peiora, haeretice, facis quam quae fecit Iudaeus".

${ }^{31}$ Cf. ibidem 2, 4, 11, CCL 60, 339; ibidem 3, 4, 16, CCL 60, 355.

${ }^{32}$ Cf. e.g. ibidem 3, 5, 3-12, CCL 60, 356f.

${ }^{33}$ For an English translation of the three sermons and a study on pre-baptismal rites, cf. Quodvultdeus of Carthage, The Creedal Homilies: Conversion in Fifth-Century North Africa, ed. F.M. Finn, ACW 60, Mahwah (NJ) 2004.

${ }^{34} \mathrm{R}$. Braun's edition of the works attributed to Quodvultdeus is followed in this paper: Opera Quodvultdeo Carthaginiensi episcopo tributa, CCL 60.

${ }^{35}$ The liturgical context of De symbolo 1-3 has been studied by T.M. Finn, Quodvultdeus: The Preacher and the Audience. The Homilies on the Creed, StPatr 31 (1997) 42-58; idem, Introduction, in: Quodvultdeus, The Creedal Homilies, p. 3-10.

${ }^{36}$ The text of Quodvultdeus' baptismal creed can be extracted from De symbolo 1-3, as well as from Contra Iudaeos, Paganos et Arrianos: for the text, cf. J.N.D. Kelly, Early Christian Doctrines, London 1960, 175-176. V. Saxer, Les rites de l'initiation chrétienne du IIe au VIe siècle, Spoleto 1988, 403 sets De accedentibus ad gratiam 1-2 between the inscription of the candidates for baptism and the renunciation of the devil; De accedentibus ad gratiam 1, 2, 1-5, CCL 60, 441f. speaks about renunciation in the perfect tense and therefore had to be delivered after the rite. Nazzaro, La produzione omiletica, p. 38, and J. De Simone, The Baptismal and Christological Catechesis of Quodvultdeus, "Augustinianum" 25 (1985) 277, assume that Contra Iudaeos, Paganos et Arrianos was delivered during the Easter Vigil; F. Mbonigaba, La traditio symboli nell'Africa cristiana all'epoca 
petentes - the candidates for baptism - and to illuminate them about the faith they were set to confess during their baptism on Easter Night of the same week. The instruction of catechumens in Carthage culminated with three impressive rites: the scrutinies ${ }^{37}$, the renunciation of the devil, and the traditio symboli ${ }^{38}$. In this way, the catechumens, carried by the Church during the catechumenate in her womb, were prepared for their birth ${ }^{39}$. These three rites are crucial in understanding the language of Quodvultdeus' sermons on the Creed, since they create a unity considered in the sermons.

The scrutinies were the first rite exercised on the night, proceeding in a rather harsh way. Each candidate, regardless of his or her social status ${ }^{40}$, was presented to the congregation humiliated, barefoot and wearing a goatskin in a representation of the slave of Satan. Their physical states were examined. The exorcist would invoke biblical quotes and bark at the devil within each candidate. The rite culminated with the exsufflatio ${ }^{41}$ : in an attempt to expel the devil, each of the candidates was grabbed, after which the exorcist would hiss in his or her face ${ }^{42}$. After Satan, their "Slave-holder", had fled, the candidates were prepared for the next step: to make their free decision in renouncing the devil, together with all his "pomps" and "service"43.

With this renunciation, the old pact of one's allegiance would be broken, and the candidate would be prepared to accept a new Master and new deal

dell'invasione dei Vandali: introduzione, testo latino e traduzione italiana del Contra Iudaeos, Paganos et Arrianos di Quodvultdeus di Cartagine, Roma 2015, 67 describes it as a catechesis on the traditio symboli, similar to the other sermons. Neither of these positions, though, has been supported by arguments. Although the spousal imagery used in Contra Iudaeos, Paganos et Arrianos applied to Christ and the Church, because of the use of Rom 13:13 and the impression that the first part of Contra Iudaeos, Paganos et Arrianos can be understood as the abrenuntiatio (which was a part of the baptismal rites in Africa) I prefer to leave this question open. Contra Iudaeos, Paganos et Arrianos is still a sermon on the Creed, delivered in the liturgical context of Quodvultdeus' (pre-) baptismal catechesis.

${ }^{37}$ The rites in Augustine are examined by J. Quasten, Ein Taufexorzismus bei Augustinus, REA 2 (1956) 101-108.

${ }^{38}$ Pre-baptismal rites during Quodvultdeus' time in Carthage are examined by E. Ferguson, Baptism in the Early Church: History, Theology, and Liturgy in the First Five Centuries, Grand Rapids (Mich.) 2009, 771-775; H.A. Kelly, The Devil at Baptism: Ritual, Theology, and Drama, Eugene (OR) 2004, 106-122.

${ }^{39} \mathrm{Cf}$. Quodvultdeus, De symbolo 3, 1, 1, CCL 60, 349.

${ }^{40} \mathrm{Cf}$. ibidem 1, 1, 8, CCL 60, 305.

${ }^{41}$ D. Van Slyke (Breathing Blessing, Bestowing the Spirit: 'Insufflatio'as a Distinct Ritual Gesture in Ancient Christian Initiation, EL 121 (2007) fasc. 3, 301-327) distinguishes between liturgical acts of exsufflatio and insufflatio not only in Quodvultdeus, but in Ancient and Medieval liturgy as well.

${ }^{42}$ Cf. W. Harmless, Augustine and the Catechumenate, Collegeville (Minn.) 1995, 274-86; D.E. Serra, New Observations about the Scrutinies of the Elect in Early Roman Practice, "Worship" 80 (2006) fasc. 6, 521-523.

${ }^{43}$ D. Van Slyke (The Devil and His Pomps in Fifth-Century Carthage: Renouncing Spectacula with Spectacular Imagery, DOP 59:2005, 53-72) places this renunciation in the context of the life of Carthage during Quodvultdeus' time. 
expressed by the symbolum, the baptismal Creed of the Church of Carthage. Handing over of the Creed was not merely an instructive act, but rather formed part of a group of rites focused on changing the spiritual realm to which the candidates belonged. It is in this context that I wish to assess Quodvultdeus' statements and figures of speech present in his catecheses. If the rites themselves were highly impressive and "awe-inspiring", their meaning was underlined by the no less powerful language of the bishop's instruction. The motivation for this was not an external polemic against non-Catholic groups. It was rather to edify the instructed candidates and the presented congregation of the Christian faithful in order that they might cling to the Church and her doctrine in giving new life and adherence to God revealed in Christ.

The instruction for catechumens in Antiquity generally focused on providing them with the moral and spiritual knowledge they would need after renouncing the devil and embracing life in Christ through baptism. In this formation, the Creed played a significant role. The emphasis on the correct profession of faith implied a focus on the true understanding of the faith to be professed during baptism and to be retained throughout the whole life of the Christian believer ${ }^{44}$. The primary aim of a bishop in one of the last sermons before the baptism of the newcomers would not therefore be to attack other religious groups, but rather to edify the faith of the candidates and "feed" them with the "proper food" of the "Mother Church" 45 in order that they might "remain in her" 46 . Therefore, the "sacrament of the Creed" would be explained to the candidates for baptism, as Quodvultdeus considered it "the foundation of the Catholic faith built by the hands of apostles and prophets", on which "the building of the Church has risen" ${ }^{47}$. A sound faith was necessary for anyone who desired to enter the "building of the Church" to seek baptism, salvation, and eternal life $\mathrm{e}^{48}$.

The three rites constitute a single movement aimed at changing the candidate's allegiance from the devil to Christ and his Church. With the first rite, the candidate is enabled to make a free choice; with the second, the candidate gets rid of the devil that enslaves him or her. With the final acceptance of the Creed the candidate adheres to the new master, Christ ${ }^{49}$. Abandoning the inheritance of the devil, the candidate is ready to claim the inheritance of Christ

${ }^{44}$ Cf. A. Casiday, Sin and Salvation: Experiences and Reflections, in: Cambridge History of Christianity, ed. A. Casiday - F.W. Norris, vol. 2, Cambridge 2007, 504-505.

${ }^{45}$ Cf. Quodvultdeus, De symbolo 1, 1, 3, CCL 60, 305; ibidem 3, 1, 1, CCL 60, 349.

${ }^{46}$ Cf. ibidem 1, 13, 11, CCL 60, 334.

${ }^{47}$ Ibidem 2, 1, 1, CCL 60, 335: "Sacramentum symboli quod accepistis [...] noveritis hoc esse fidei catholicae fundamentum, super quod aedificium surrexit ecclesiae, constructum manibus apostolorum et prophetarum".

${ }^{48}$ Cf. idem, Contra Iudaeos, Paganos et Arrianos 1, 4, CCL 60, 228.

${ }^{49}$ Cf. idem, De symbolo 2, 2, 1, CCL 60, 335; idem, Contra Iudaeos, Paganos et Arrianos 1, 8, CCL 60, 227-228. 
by adhering to his or her faith ${ }^{50}$. Quodvultdeus faithfully follows Augustine's emphasis on the faith that seeks understanding (credo ut intelligam) ${ }^{51}$. He is convinced that knowledge of the faith of the Church makes the believer stand fast in his or her spiritual struggle, as it is the Church that "arms young men with the strength of virtue against the devil"'52.

What is the meaning, then, of his speaking about heretic doctrines, pagan views, and Jewish belief in his exposition of the Creed? Two purposes can be considered. The first attempts to explain Catholic doctrine. The second underlines through faith that only within the Catholic Church can one seek salvation. This is done in order to encourage the believer - no matter what - to stay in it, in spite of the many pressures to change ecclesiastical allegiance, and to "persevere without fail" ${ }_{53}$. In one of the sermons, the bishop encourages new Christians to "believe in such a way that you might see what you desire" 54 . He is concerned with the faith of his audience and faith at work, a faith not limited to useless dogma but one that allows God and eternal life to be found. For this, it is necessary, according to Quodvultdeus' belief, to be part of the Church, i.e. the Catholic Church, because whoever is not in the Church "is able neither to love nor to hold" God "dear", for that person may never be "with God, who is eternal life" 55 .

In fact, the link between the Church and salvation is a crucial one for Quodvultdeus. Most of the invectives against the heretics found in the sermons are espoused in the context of the Church. The heresy injures the Church, the bride of Christ, and she is grieved by these insults ${ }^{56}$. Quodvultdeus follows Augustine's teaching on Christus totus, Christ being present both in the head and in the body of the Church ${ }^{57}$. For him, both realities of Christ and the Church cannot be divided: it is essential to hold on to the faith of the Church. The bishop sees the baptismal Creed and the entirety of its Catholic, non-heretical comprehension as "protection against the poison of the serpent" 58 .

The liturgical context shows that the sermons were not pronounced against the heretics in person. Indeed, Quodvultdeus made frequent use of the apostrophe. This figure of speech, which he used to address the absent heretics, allowed him not only to "teach" (docere) using rational arguments, but to fulfil the other two duties of the orator (officia oratoris): to "entertain" (delectare) through the elegance of his speech, and to "shake" them or "fill them with indignation" (movere/flectere) by unmasking opposing views. His orations on heresies

\footnotetext{
${ }^{50}$ Cf. idem, Contra Iudaeos, Paganos et Arrianos 3, 1, CCL 60, 229.

${ }^{51}$ Cf. idem, De symbolo 2, 2, 2, CCL 60, 335.

${ }^{52}$ Ibidem 2, 13, 8, CCL 60, 348: "quae iuvenes robore virtutis contra diabolum armat".

${ }^{53}$ Ibidem 2, 13, 9, CCL 60, 348: "secum perseverantes indeficienter pascit". Cf. ibidem 3, 1, 7-8.14-16, CCL 60, 349-350.

${ }^{54}$ Ibidem 3, 2, 1, CCL 60, 351: "Sic crede, ut desideres videre quod credis".

${ }^{55}$ Ibidem, 2, 13, 6, CCL 60, 348: "nec cum Deo est, qui aeterna vita est".

${ }^{56} \mathrm{Cf}$. ibidem 3, 13, 5, CCL 60, 362.

${ }^{57}$ Cf. idem, Contra Iudaeos, Paganos et Arrianos 22, 2, CCL 60, 256.

${ }^{58}$ Idem, De symbolo 3, 1, 4, CCL 60, 349: "protectionem parturientis contra venena serpentis".
} 
(including the example of the struggle with a "hermeneutical" heretic) $)^{59}$ was therefore aimed at edifying the faith of those Christian believers present. The sermons that contained catechesis were not, in general, a polemical genre.

3. Heresies in other works on the Creed of the period. We can place Quodvultdeus' instruction in the Creed in the context of other Patristic works of this period that contain an exposition of the Creed. Is Quodvultdeus the only Christian writer who speaks about heretics in this kind of literature?

The oldest of such writings, the explanatio symboli attributed to Ambrose of Milan and dated to the last quarter of the $4^{\text {th }}$ century is a short catechesis addressed to candidates for baptism on the occasion of the traditio symboli. Ambrose presents the symbolum as the summary of a teaching of the Apostles not to be tampered with ${ }^{60}$. He plays with the double meaning of the Latin word fides in warning that altering the received faith (fides) makes the believer dishonest and unworthy of trust $(\text { fides })^{61}$. Indeed, altering the text of the Creed is characteristic of the heretic ${ }^{62}$, a violation of the limits of the faith (defined and expressed by the apostles in the Creed) received by the Roman Church, the seat of Peter, "the first one among the Apostles" ${ }^{3}$. In this way, Ambrose even criticises the practice of changing the wording of the Creed as a zealous Catholic reaction to various emerging heresies, such as Patripassianism (or Sabellianism) ${ }^{64}$, since they might take advantage of such an alteration to promote erroneous views on the Trinity ${ }^{65}$. Ambrose, therefore, does not use the catechesis on the Creed as an opportunity to fight against heresies. In mentioning them, he edifies the faith his audience receives by delimiting it to the teaching of the Apostles: his critics of heresies in the Explanatio symboli do not have a polemical, but rather a catechetical function.

Although Rufinus' Expositio symboli, dated to the beginning of the $5^{\text {th }}$ century, did not originate as an oral form of instruction for baptismal candidates, it still aimed to expound on the $\mathrm{Creed}^{66}$. The faith of the Church, expressed in the Apostles' Creed, is here contrasted not only by pagans, but by heretics too.

${ }^{59} \mathrm{Cf}$. the analogical title of F.T. Harkins, Nuancing Augustine's Hermeneutical Jew: Allegory and Actual Jews in the Bishop's Sermons, "Journal for the Study of Judaism" 36 (2005) fasc. 1, 41-64, which states that Augustine did not compete with an actual Jew present at his preaching, but nevertheless reacted to the Jewish presence in Africa.

${ }^{60} \mathrm{Cf}$. Ambrosius, Explanatio symboli 2, ed. G. Banterle, SAEMO 17, Milano - Roma 1982, 26; ibidem 3, SAEMO 17, 30.

${ }^{61}$ Cf. ibidem 7, SAEMO 17, 36. For the theology of fides in Ambrose, cf. D. Vopřada, La mistagogia del Commento al Salmo 118 di sant'Ambrogio, Roma 2016, 119-120.

${ }^{62} \mathrm{Cf}$. Ambrosius, Explanatio symboli 2, SAEMO 17, 26-28.

${ }^{63} \mathrm{Cf}$. ibidem 3, SAEMO 17, 30; 7, SAEMO 17, 36.

${ }^{64} \mathrm{Cf}$. ibidem 2, SAEMO 17, 28; 4, SAEMO 17, 30. The same stance is confirmed by Rufinus, Expositio symboli 3, ed. M. Simonetti, CCL 20, Turnhout 1961, 136; 5, CCL 20, 140.

${ }^{65} \mathrm{Cf}$. Ambrosius, Explanatio symboli 4, SAEMO 17, 30.

${ }^{66}$ Cf. Rufinus, Expositio symboli 1, CCL 20, 133. 
Erroneous views of the heretics are presented in order to expound the meaning of the Creed ${ }^{67}$.

Saint Augustine, Bishop of Hippo (d. 430), composed numerous works on the Creed. The first was De fide et symbolo, a revision of his address to the Council of Carthage in 393. Although Augustine does not mention heresies by name in this work, the references to heretic doctrines that "poison" the faith expressed in the Creed are still present in nearly every commentary on the singular articles of faith ${ }^{68}$. Sermones 212-214, given during the rite of traditio symboli, and Sermo 215, delivered during the rite of redditio symboli, contain only very scarce remarks on the rejection by heretics, pagans, and Jews of the singular articles of faith ${ }^{69}$. The explanation in these sermons is theologically very acute and reveals that Augustine had no objections in using the intricacies of theological distinctions, even when instructing his general audience.

Augustine's sermon De symbolo ad catechumenos represents another wellstructured article-by-article commentary on the Creed. In fact, Quodvultdeus follows its style so closely that his three catecheses De symbolo are inserted into the manuscripts right behind the genuine work by Augustine ${ }^{70}$. Even in this sermon, Augustine sets out to redress some of the views attributed to Catholic Christians by heretical groups. Such is the case with the Arian accusation that the Catholics introduced a belief in two gods: Father and Son ${ }^{71}$. His exposition even assumes an apologetic function when he states, for example: "This is what the blasphemous Arian heretics say, not me!"72. Nevertheless, Augustine presents the Church as being surrounded by various heretical groups. But he reminds the reader that they must be fought against and not fought over because the Gospel promises "the gates of hell shall not prevail against her" 73 . Again, this statement points to the uniqueness and steadfastness of the Church, not directly against the heretics. Also, through the Catholic refusal to rebaptise heretics, his statement should not be understood as a polemic against rebaptism, but rather a statement in support of the power of baptism imparted to the audience, the candidates for baptism ${ }^{74}$. Furthermore, Augustine mentions in two passages that it was the Jews who "arrested, insulted, bound [... and]

${ }^{67}$ Cf. ibidem 37, CCL 20, 173; 39, CCL 20, 175.

${ }^{68} \mathrm{Cf}$. Augustinus, De fide et symbolo 1,$1 ; 2,3 ; 3,3 ; 4,5 ; 4,7 ; 4,8 ; 6,13 ; 7,14 ; 9,18 ; 9,19$; 9, 20; 10, 21.

${ }^{69}$ Cf. e.g. idem, Sermo 215, 7, PL 38, 1075-1076.

${ }^{70}$ Cf. A.D. Fitzgerald, De symbolo ad catechumenos, in: Augustine through the Ages: an Encyclopaedia, ed. idem, Grand Rapids (MI) 1999, 820.

${ }^{71}$ Cf. Augustinus, De symbolo ad catechumenos 2, 4, ed. R. Vander Plaetse, CCL 46, Turnhout 1969, 187-188.

${ }^{72}$ Ibidem 2, 5, CCL 46, 189: "Hoc ariani haeretici blasphemi dicunt, non ego".

${ }^{73}$ Ibidem 6, 14, CCL 46, 197: "ipsa est ecclesia sancta, ecclesia una, ecclesia vera, ecclesia catholica, contra omnes haereses pugnans: pugnare potest, expugnari tamen non potest. [...] portae inferorum non vincent eam".

${ }^{74}$ Cf. ibidem 8, 16, CCL 46, 198-199. 
dishonoured" Jesus, who crowned him with thorns, spat at him, "scourged him, overwhelmed him with revilings, hanged him upon the tree, pierced him with a spear", and "killed him" before burying him ${ }^{75}$. These remarks are only circumstantial and are not intended as merging with the polemics ${ }^{76}$.

Another group of sermons on the Creed was preached and written by Peter Chrysologus in Ravenna towards the mid- $5^{\text {th }}$ century ${ }^{77}$. Even this corpus of texts is not void of references to the heretics. Chrysologus invites his listeners to "cleanse their hearts from the dirt of perfidy", which is incompatible with faith, in order for it to flourish ${ }^{78}$. In this way, he somewhat explains the articles of the Creed as contrasting with polytheistic ${ }^{79}$ and Arian beliefs ${ }^{80}$. The Jews and the heretics accept the Creed only to some extent ${ }^{81}$. The bishop even tries to respond to the objections of the heretics to the Catholic faith ${ }^{82}$. He does not hesitate to turn rhetorically to the heretics with a highly polemical tone: "Heretic, if you hear this, do not say"83, or invites the absent heretic to accept the faith he explains ${ }^{84}$. And in serving to make the exposition more appealing to the candidates for baptism, it also edifies the audience.

Therefore, it is evident that it was not exceptional to address heretics and other non-Catholic groups in the works related to the exposition or instruction of the Creed. When trying to transmit the correct conception of faith to the candidates for baptism and other Christian believers, it made sense to define the correct comprehension of faith even against the background of erroneous beliefs. Quodvultdeus' catechesis on the Creed follows the tradition of creedal exposition espoused by the Latin Fathers of the era.

4. Religious and historical context. The modern reader may understand the rhetoric in Quodvultdeus' sermons on the Creed much better if today's comprehension of religious adherence is replaced with the ancient perception of religion. Most converts to Catholic Christianity in the $5^{\text {th }}$ century were part of an extremely vivid religious environment. They certainly had general

${ }^{75}$ Ibidem 3, 10, CCL 46, 195: "Tenent Iudaei, insultant Iudaei, ligant Iudaei, spinis coronant, sputis dehonestant, flagellant, opprobriis obruunt, ligno suspendunt, lancea fodiunt, postremo sepeliunt; quasi relictus est"; 7, 15, CCL 46, 198: "Iudaei tamen eum occiderunt".

${ }^{76} \mathrm{In}$ terms of current research and a concise study of the relation of Augustine to the Jews, I refer to J. van Oort, Iudaei, AL III 781-792.

${ }^{77}$ Cf. Petrus Chrysologus, Sermones 55-62bis, ed. A. Olivar, CCL 24, Turnhout 1975, 372-428.

${ }^{78}$ Ibidem 61, 2, CCL 24, 410: "de cordibus vestris expurgate perfidiae coenum". Cf. ibidem 62bis, 1, CCL 24, 426.

${ }^{79} \mathrm{Cf}$. ibidem 57, 3, CCL 24, 384; 59, 3, CCL 24, 396; 60, 3, CCL 24, 402-404; 61, 3, CCL 24, 412.

${ }^{80}$ Cf. ibidem 58, 5, CCL 24, 392; 59, 4, CCL 24, 396; 61, 3, CCL 24, 412; 62, 6, CCL 24, 420.

${ }^{81} \mathrm{Cf}$. ibidem 62, 10, CCL 24, 424.

${ }^{82}$ Cf. ibidem 60, 4, CCL 24, 404.

${ }^{83}$ Ibidem 60, 4, CCL 24, 404: "Sed haec audiens, haeretice, ne dicas". Cf. also ibidem 62, 9 , CCL 24, 422.

${ }^{84}$ Cf. ibidem 60, 7, CCL 24, 406. 
cultural notions or even personal experience with pagan polytheism, the presence of Jews and their cult. They also knew about the divisions and struggles at play among different Christian groups: Catholics, Donatists, but also Manichaeans and Arians ${ }^{85}$. As with converts of any age they brought to the Church their understanding of religious truths and attitudes, of which Christian bishops such as Ambrose or Augustine were well aware.

Moreover, the imperial legislation favouring Catholic Christianity from the 380 s onwards seems to have brought the various dissenting groups - the pagans, Jews, Arians, and (later in Africa) also the Donatists and Manichaeans - into an alliance ${ }^{86}$. Both Ambrose and Augustine depict the Church as surrounded by these "enemies of the faith". This tense religious atmosphere must have become even more heated when the Arian Vandals arrived to conquer Africa, using violence against the majority of the Roman and Catholic population.

Quodvultdeus, as a deacon and later as the Bishop of Carthage, must have faced this first aspect when instructing the competentes. He was aware that he had to instruct the candidates thoroughly to avoid any misconceptions about the doctrine of faith. The baptismal Creed offered a solid basis for the transmission of this doctrine and instruction and we have sufficient reasons to believe Quodvultdeus saw the need for firm instruction. His catecheses are lengthier than those of Ambrose, Peter Chrysologus, and even Augustine. His theology is apologetic, which he is forced into given the many contrasting religious views. A vivid polemic of the heretical doctrines might even have been entertaining for the audience as part of the preacher's "spectacular imagery", designed to keep their attention during the lengthy exposition ${ }^{87}$.

Moreover, there is another important religious and historical reason. Because of the establishment of Catholic Christianity in the last decades of the $4^{\text {th }}$ century, it was better from a social perspective to be a Catholic Christian than not. It helped people in terms of economic and political status and also offered new opportunities even for marriage. However, with the Vandal danger, this changed profoundly. Still, there must have been a great spiritual hunger among people living in a disarrayed world and a politically unstable situation. This anxiety moved people to the act of conversion associated with baptism. From a social and economic point of view, it was becoming more and more hazardous to join the Catholic Church. This step did not promise much on the eve of the Vandal invasion, whose hostile approach to the Catholics was well known.

${ }^{85}$ The difficult religious situation of Africa under the Vandals is well portrayed by A.H. Merrills - R. Miles, The Vandals, Chichester 2013, esp. 177-203. For a more theological study of various Christian heresies and other religious groups in Carthage during the $5^{\text {th }}$ century, cf. González Salinero, Poder y conflicto, p. 49-76; Van Slyke, Quodvultdeus of Carthage, p. 147-201.

${ }^{86}$ Cf. M. Meslin, Les Ariens d'Occident, 335-430, Paris 1967, 331-335; L. Cracco Ruggini, Ambrogio e le opposizioni anticattoliche fra il 383 e il 390, "Augustinianum" 14 (1974) 424; Voprada, La mistagogia, p. 44-45.

${ }^{87}$ Cf. Van Slyke, The Devil and His Pomps in Fifth-Century Carthage, p. 53-72. 
In line with African theology, Quodvultdeus was convinced that "outside the Church, there [could be] no salvation". The bishop's maxim was that the baptised would remain in the Church even though they might be disadvantaged by, and face repercussions from, their adherence to the Catholic Church. The Creed and the faith expressed in it were to become their defensive wall. For this, the clear exposition of the content of the Creed and its delimitation from pagan, Jewish, and especially Arian understanding was crucial. Here again, stemming from an apologetic purpose, Quodvultdeus' aims were to edify his new Church members and make them steadfast in their faith.

Although Quodvultdeus' sermons contain anti-heretical language that could be understood as harsh by a modern reader, it needs to be placed in the context of the liturgy and the bishop's ministry. The studied works are not primarily anti-heretical; they rather focus on affirming the doctrine of the Church and on the adherence of the newly baptised to the Church as a means of salvation. Quodvultdeus' approach to the heretics in the course of his exposition of the Creed has a catechetical function, and it is not exceptional in the Latin tradition of catechesis during the $4^{\text {th }}$ and $5^{\text {th }}$ centuries. His use of approaching the most probably absent heretics and other non-Catholics in his preaching helped to entertain the public and deflect from their annoyance at the length of his speeches. In this way the bishop was able to offer a kind of new spectacle that would draw his audience in instead of the type preferred by the theatre of pagan worship.

There is no doubt that Quodvultdeus lived in a troubled season of the Church's history. It seems to be an experience of all churches operating in times of persecution to use an apologetic or polemical approach much more than in peaceful times when there is less need to strengthen the Christian identity of the believers and their allegiance to the Church. In this way, I would opt to reassess the up-to-now strong notion of Quodvultdeus as an anti-heretical polemicist and encourage a depiction of him more as a man dedicated to his ministry as a bishop during an extremely tough time for the Church that he tried to serve.

\section{(Summary)}

The sermons of Quodvultdeus Bishop of Carthage during the time of the Vandal invasion of Africa are characterised by their harsh polemics against the Jews, Pagans, and Arians (De symbolo 1-3; Contra Iudaeos, paganos, et Arrianos; De accedentibus ad gratiam 1-2). The polemics against the Arians derived from the fact that the new lords of Africa, the Vandals, were Arians who promoted their 
belief and persecuted the Romans for professing their Catholic faith. This paper aims to reassess the polemical character of Quodvultdeus' sermons. They are examined in their liturgical context and compared to other contemporary writings on the Creed, and finally discussed in their historical and religious context. In view of this analysis, it can be stated that the works of Quodvultdeus studied here are not primarily anti-heretical, but they rather focus on affirming the doctrine of the Church and on the adherence of the newly baptised to the Church as a means of salvation. Quodvultdeus' harsh anti-heretical language is not exceptional in the Latin tradition of creedal catechesis during the $4^{\text {th }}$ and $5^{\text {th }}$ centuries and has therefore chiefly a catechetical function.

\section{MOWY QUODVULTDEUSA O SYMBOLU: PONOWNA OCENA JEGO POLEMIKI PRZECIW ŻYDOM, POGANOM I ARIANOM}

\section{(Streszczenie)}

Kazania biskupa Quodvultdeusa z Kartaginy w czasach wandalskiej inwazji na Afrykę charakteryzują się ostrą polemiką przeciw Żydom, poganom i arianom (De symbolo 1-3, Contra Iudaeos, paganos i Arrianos, De accedentibus ad gratiam 1 -2). Polemika przeciw arianom wynikała z faktu, że nowi władcy Afryki, Wandalowie, byli arianami, którzy promowali swą wiarę i prześladowali Rzymian za wyznawanie wiary katolickiej. Celem niniejszego artykułu jest dokonanie ponownej oceny polemicznego charakteru kazań Quodvultdeusa. Autor bada je w ich kontekście liturgicznym oraz porównuje z innymi współczesnymi pismami dotyczącymi Credo, a wreszcie omawia w kontekście historycznym i religijnym. Dzieki tej analizie można stwierdzić, że omawiane tutaj dzieła Quodvultdeusa nie maja przede wszystkim charakteru antyheretyckiego, ale raczej koncentrują się na potwierdzeniu doktryny Kościoła i aprobaty nowo ochrzczonych dla Kościoła jako pośrednika zbawienia. Ostra inwektywa Quodvultdeusa nie była czymś wyjątkowym w łacińskiej tradycji katechezy wyznaniowej IV i V wieku i dlatego odgrywa zasadniczo funkcję katechetyczną.

Key words: Latin Patristics, $5^{\text {th }}$ century, Quodvultdeus, Vandals, heresy, Arianism, preaching, catechumenate, catechesis.

Słowa kluczowe: łacińska patrystyka, V wiek, Quodvultdeus, Wandalowie, herezja, arianizm, kaznodziejstwo, katechumenat, katecheza.

\section{BIBLIOGRAPHY}

\section{Sources}

Ambrosius, Explanatio symboli, ed. G. Banterle, SAEMO 17, Milano - Roma 1982, 11-41. Augustinus, De fide et symbolo, ed. J. Zycha, CSEL 41, Vindobonae 1900, 1-32. 
Augustinus, De symbolo ad catechumenos, ed. R. Vander Plaetse, CCL 46, Turnhout 1969, 179-199.

Augustinus, Sermones, PL 38.

Codex Theodosianus, ed. Th. Mommsen - P.M. Meyer, Berlin 1905.

Cyprianus, Epistulae, ed. W. Hartel, CSEL 3/2, Vindobonae 1871.

Didache, ed. A. Lindemann - H. Paulsen, in: Die Apostolischen Väter, Tübingen 1992, 1-21.

Epistula Pseudo-Barnabae, ed. A. Lindemann - H. Paulsen, in: Die Apostolischen Väter, Tübingen 1992, 54-74.

Petrus Chrysologus, Sermones, ed. A. Olivar, CCL 24, Turnhout 1975.

Quodvultdeus, Contra Iudaeos, paganos et Arianos, ed. R. Braun, CCL 60, Turnhout 1976, 227-258.

Quodvultdeus, De accedentibus ad gratiam, ed. R. Braun, CCL 60, Turnhout 1976, 459-470.

Quodvultdeus, De promissionibus et praedicationibus Dei, ed. R. Braun, CCL 60, Turnhout 1976, 1-223.

Quodvultdeus, De symbolo, ed. R. Braun, CCL 60, Turnhout 1976, 305-363.

Rufinus, Expositio symboli, ed. M. Simonetti, CCL 20, Turnhout 1961, 125-182.

Literature

Cameron A., The Last Pagans of Rome, Oxford 2011.

Casiday A., Sin and Salvation: Experiences and Reflections, in: Cambridge History of Christianity, ed. A. Casiday - F.W. Norris, vol. 2, Cambridge 2007, 501-530.

Cracco Ruggini L., Ambrogio e le opposizioni anticattoliche fra il 383 e il 390, "Augustinianum" 14 (1974) 409-449.

Escribano Paño M.V., El Edicto de Tesalónica (CTh 16, 1, 2. 380) y Teodosio: norma antiarriana y declaración programática, "Cassiodorus" 5 (1999) 35-64.

Ferguson E., Baptism in the Early Church: History, Theology, and Liturgy in the First Five Centuries, Grand Rapids (Mich.) 2009.

FInN T.M., Introduction, in: Quodvultdeus of Carthage, The Creedal Homilies: Conversion in Fifth-Century North Africa, ed. F.M. Finn, ACW 60, Mahwah (NJ) 2004, 1-22.

Finn T.M., Quodvultdeus: The Preacher and the Audience. The Homilies on the Creed, StPatr 31 (1997) 42-58.

Fitzgerald A.D., De symbolo ad catechumenos, in: Augustine through the Ages: an Encyclopaedia, ed. idem, Grand Rapids (MI) 1999, 820.

Gaudemet J., L'Edit de Thessalonique: police locale ou déclaration de principe?, in: Aspects of the Fourth Century A.D. Proceedings of the symposium Power \& possession: State, society, and church in the fourth century A.D. held on the occasion of the fifth anniversary of the interdisciplinary debating society AGAPE. Leiden, 3-5 June 1993, ed. H.W. Pleket - A.M.F.W. Verhoogt, Leiden 1997, 43-51.

González Salinero R., Poder y conflicto religioso en el norte de África: Quodvultdeus de Cartago y los vándalos, Madrid 2002.

Harkins F.T., Nuancing Augustine's Hermeneutical Jew: Allegory and Actual Jews in the Bishop's Sermons, "Journal for the Study of Judaism" 36 (2005) fasc. 1, 41-64.

Harmless W., Augustine and the Catechumenate, Collegeville (Minn.) 1995.

Kelly H.A., The Devil at Baptism: Ritual, Theology, and Drama, Eugene (OR) 2004.

Kelly J.N.D., Early Christian Doctrines, London 1960.

Leinhard J.T., From Gwatkin Onwards: A Guide through a Century and a Quarter of Studies on Arianism, AugSt 44 (2013) 265-285.

MARA M.R., Arriani, AL I 450-459. 
Mbonigaba F., La traditio symboli nell'Africa cristiana all'epoca dell'invasione dei Vandali: introduzione, testo latino e traduzione italiana del Contra Iudaeos, paganos et Arianos di Quodvultdeus di Cartagine, Roma 2015.

Merrills A.H. - Miles R., The Vandals, Chichester 2013.

Meslin M., Les Ariens d'Occident, 335-430, Paris 1967.

Morin G., Pour une future édition des opuscules de s. Quodvultdeus évêque de Carthage au Ve siècle, RBen 31 (1914-1919) 156-162.

Nazzaro A.V., La produzione omiletica del vescovo di Cartagine Quoduultdeus, in: Le forme e i luoghi della predicazione. Atti del Seminario internazionale di studi (Macerata 21-23 novembre 2006), ed. G. Frenguelli - C. Micaelli, Macerata 2009, 26-67.

OORT VAN J., Iudaei, AL III 781-792.

Quasten J., Ein Taufexorzismus bei Augustinus, REA 2 (1956) 101-108.

Rodolfi A., A Difficult Co-Existence in Vandal Africa: King Geiseric and the Catholics, StPatr 39 (2006) 117-123.

SAXER V., Les rites de l'initiation chrétienne du II au VI siècle, Spoleto 1988.

SERra D.E., New Observations about the Scrutinies of the Elect in Early Roman Practice, "Worship" 80 (2006) fasc. 6, 521-523.

Simone J. DE, The Baptismal and Christological Catechesis of Quodvultdeus, "Augustinianum" 25 (1985) 265-282.

Slyke D. VAn, Breathing Blessing, Bestowing the Spirit: 'Insufflatio' as a Distinct Ritual Gesture in Ancient Christian Initiation, EL 121 (2007) fasc. 3, 301-327.

Slyke D. Van, Quodvultdeus of Carthage. The Apocalyptic Theology of a Roman African in Exile, Strathfield 2003.

Slyke D. Van, The Devil and His Pomps in Fifth-Century Carthage: Renouncing Spectacula with Spectacular Imagery, DOP 59 (2005) 53-72.

VopřAda D., La mistagogia del Commento al Salmo 118 di sant'Ambrogio, Roma 2016.

Whelan R., Arianism in Africa, in: Arianism: Roman Heresy and Barbarian Creed, ed. G.M. Berndt - R. Steinacher, Farnham 2014, 239-255. 
